\title{
DEPOSITION OF SILICA IN HYDROMETALLURGICAL PROCESSES
}

\author{
Srećko R. Stopića ${ }^{\text {, Bernd G. Friedrich }}{ }^{b}$ \\ RWTH Aachen University, IME Process Metallurgy and Metal \\ Recycling, Aachen, Federal Republic of Germany \\ a e-mail: sstopic@ime-aachen.de, corresponding author, \\ ORCID iD: (i)http://orcid.org/0000-0002-1752-5378, \\ b e-mail: bfriedrich@ime-aachen.de, \\ ORCID iD: (1)http://orcid.org/0000-0002-2934-2034
}

DOI: 10.5937/vojtehg68-21152; https://doi.org/10.5937/vojtehg68-21152

FIELD: Chemical Technology

ARTICLE TYPE: Review Article

ARTICLE LANGUAGE: English

\section{Summary:}

Introduction/purpose: Dissolution of nonferrous metals from oxidic ores such as laterite, high silicon bauxite and eudialyte during acidic treatment was connected with silica gel formation.

Methods: Familiarity with behavior of silica in hydrometallugical processes such as dissolution at atmospheric and high pressure, precipitation, neutralization and filtration is most important for the recovery of metals from water solution.

Results: Gel formation was avoided using dry digestion and a carbonation process of olivine under high pressure in an autoclave.

Conclusion: Fine silica was prepared from olivine in water solution at $175^{\circ} \mathrm{C}$ and 120 bar for 4 hours in an autoclave using some additives such as sodium bicarbonate and oxalic acid.

Key words: silicon, hydrometallurgy, gel, silica.

\section{Introduction}

Nanosilica has sparked strong interest in hydrometallurgy. Controlling silica deposition during hydrometallurgical processes has high significance for metal recovery.

ACKNOWLEDGMENTS: The research leading to these results received funding from the European Community's Seventh Framework Programme (Call identifier FP7-NMP-2012LARGE-6) under Grant Agreement $\mathrm{n}^{\circ} 309373$. This publication reflects only the author's view, exempting the Community from any liability. Project website: www.eurare.eu. 
During acid pressure leaching of ores containing silicates, pregnant liquor becames saturated with silica. Nanosilica has caused strong interest among researchers due to its interesting properties for biomedical and catalytic applications. Its synthesis can be realized by using geo-resources like olivin, nickeliferous laterites, bauxite or other high silica containing minerals. In all cases, common acidic leaching leads to gel formation which hinders an efficient synthesis process. This literature review aims at an alternative method avoiding this effect by disclosing the controlling mechanisms. The hypothesis presented is based on the preliminary experimental results accidentally obtained by the carbonation treatment of olivin minerals in the frame of a carbon capture sequestration (CCS) research results.

\section{Silica gel formation}

The treatment of silicate based ores with different acids under atmospheric pressure leads to the formation of silica gel and breaking of a leaching process. Silica gel represents an amorphous and porous form of silicon dioxide consisting of an irregular tridimensional framework of alternating silicon and oxygen atoms with nanometer-scale pores (Zulfiqar et al, 2016, pp.91-96). The dissolution of silicon from quartz or amorphous silica involves hydrolysis in the access of water to form monosilicic acid (as shown in Eq. 1). The supersaturation of $\mathrm{Si}(\mathrm{OH})_{4}$ is required for polymerization (Queneau et al, 1983). The formed precipitate represents polymerized silica in the form of a colloid, a precipitate or a gel, as shown in Figure 1.

$$
\mathrm{SiO}_{2}(\mathrm{~s})+2 \mathrm{H}_{2} \mathrm{O}=\mathrm{Si}(\mathrm{OH})_{4}(\mathrm{aq})
$$

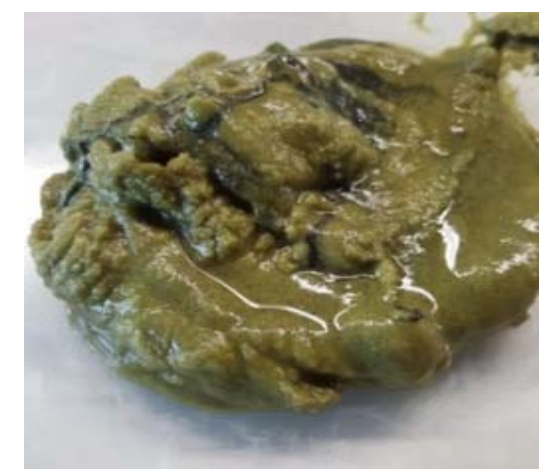

Figure 1 - Formation of silica gel

Puc. 1 - Гелеобразование из диоксида кремния Слика 1 - Формирање гела од силицијум-диоксида 
Similarly, high Si content in aluminium laterites makes these resources untreatable with acid leaching routes again due to the formation of silica gel. Alkan et al (2019, pp.266-272) studied the effects when such materials are exposed to sulfuric acid at room temperature. An empirical dry digestion-leaching model was proposed for each starting material in a comparative manner in order to prevent the formation of silica gel using sulfuric acid. As shown in Figure 2, avoiding gel formation is possible using hydrogen peroxide during acidic leaching. Nevertheless, despite this positive result, no nanosilica was formed.

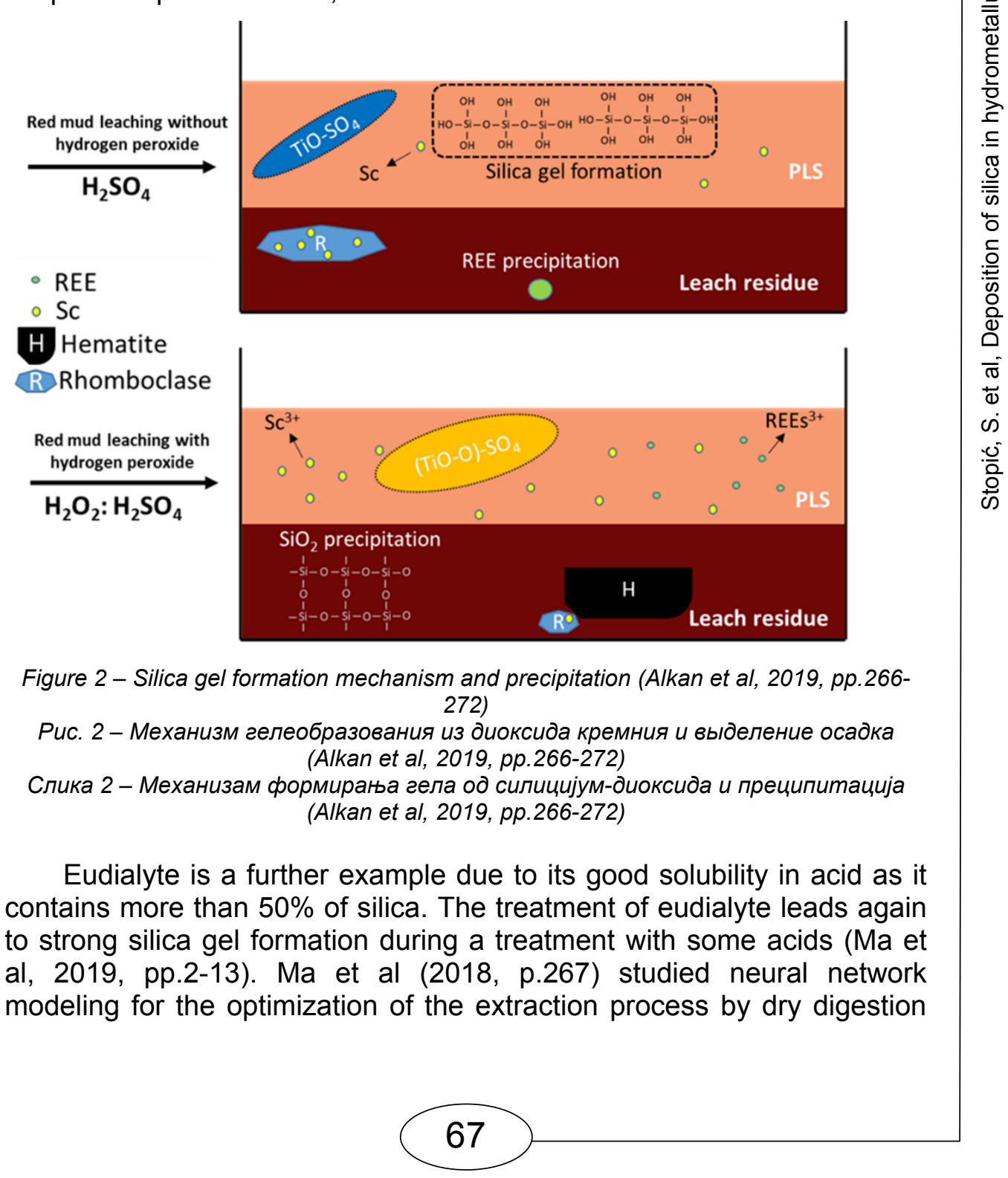


avoiding the formation of silica gel in the presence of hydrochloric acid, but again without nanosilica presence, as shown in Figure 3.

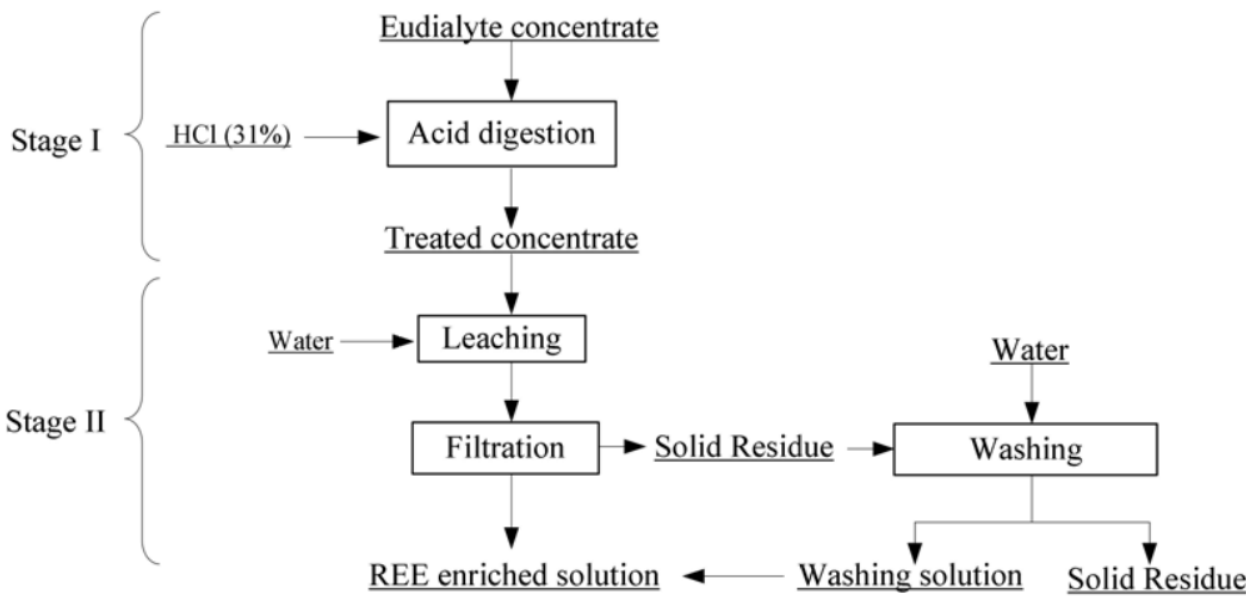

Figure 3 - Avoiding silica gel formation using the dry digestion process for the eudialyte treatment (Ma et al, 2018, p.267)

Pис. 3 - Предотвращение гелеобразования из диоксида кремния во время "Сухого» растворения при обработке эвдиалита (Ma et al, 2018, p.267)

Слика 3 - Избегавање формирања гела од силицијум-диксида током „сувог” растварања у третирању еудиалита (Ma et al, 2018, p.267)

In a method by Olerud (1998) for manufacturing silica, the leaching of natural silicates (Olivin) is performed with hydrochloric acid or other mineral acids at $110^{\circ} \mathrm{C}$, followed by draining, drying and possibly grinding up of the residue of the product obtained (US Patent 5,780,005), as shown in Fig. 4.

In order to obtain spherical silica with a controlled particle size and surface characteristics, a mineral $\left(\mathrm{Mg}_{2} \mathrm{SiO} 4\right)$ was used with the highest possible degree of purity. The product is colloidal amorphous silica in the form of a gel. The silica gel is separated from the liquid by pressure filters, washed clean of acid remains, dried and ground. The extraction of silica gel and magnesium compounds from olivine is proposed by Hansen and Zander (2011) who used sulphuric acid in a thermal treatment at temperature between 150 and $400^{\circ} \mathrm{C}$ (European Patent EP 1373139 B1) for 4 to 12 hours. 


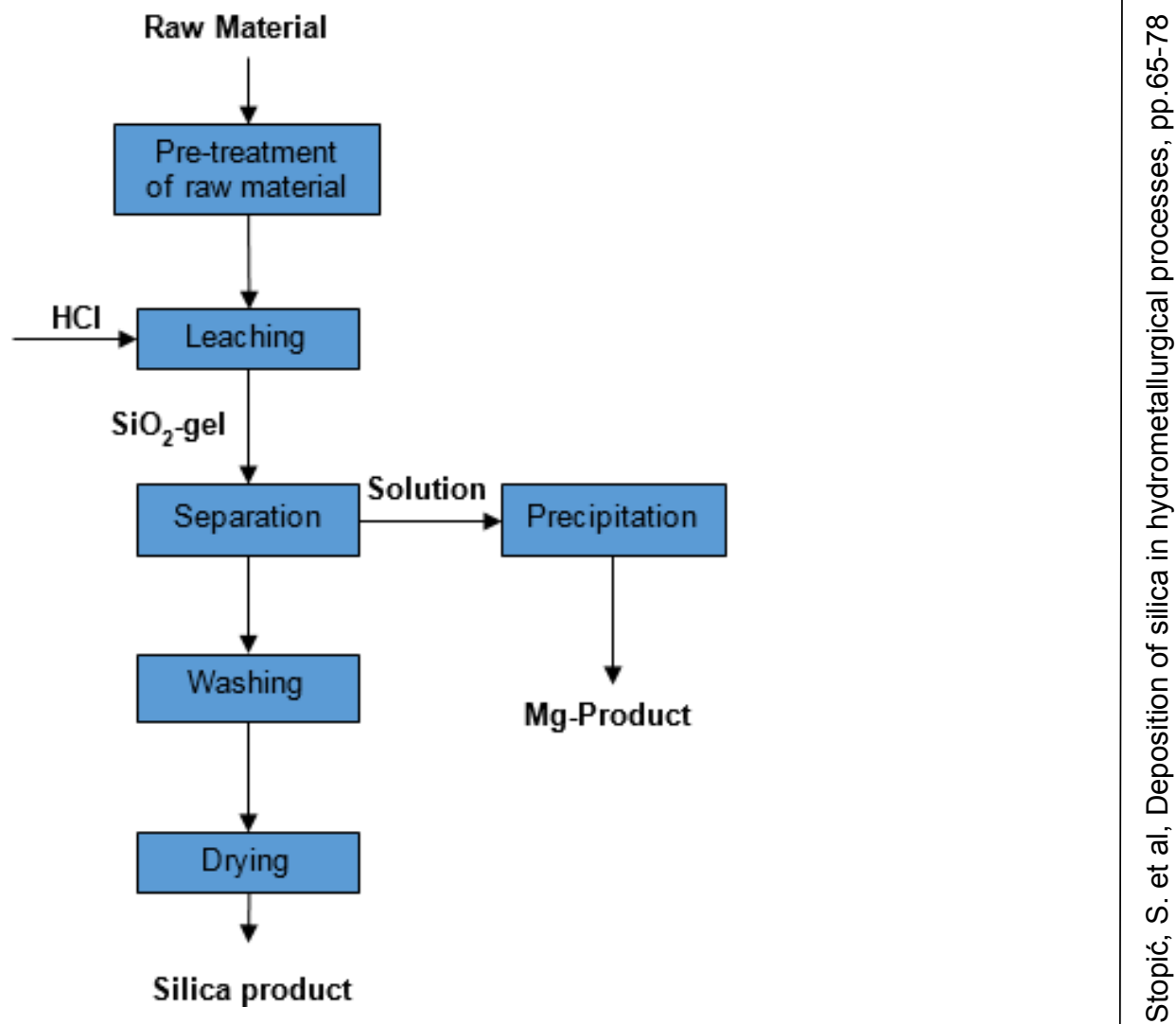

Figure 4 - Acidic method for the synthesis of silica (Olerud, 1998)

Puc. 4 - Кислотный метод для синтеза диоксида кремния (Olerud, 1998)

Слика 4 - Синтеза силицијум-диоксида методом растварања оливина киселином (Olerud, 1998)

\section{Current synthesis methods for nanosilica}

Development of ceramic nanoparticles such as silica, alumina and titania with improved properties has been studied with much success in several areas such as synthesis and surface science (Hansen \& Zander, 2011), (Stopic et al, 2013, pp.3633-3635). Advancement in nanotechnology has led to the production of nanosized silica which has been widely used as a filler in a catalysis and glass industry. Silica particles extracted from natural resources contain metal impurities and are not favorable for advanced scientific and industrial applications.

The sol-gel process is widely applied to produce silica, glass, and ceramic materials due to its ability to form pure and homogenous 
products at mild conditions. The process involves hydrolysis and condensation of metal alkoxides $\left(\mathrm{Si}(\mathrm{OR})_{4}\right)$ such as tetraethylorthosilicate (TEOS, $\left.\mathrm{Si}\left(\mathrm{OC}_{2} \mathrm{H}_{5}\right)_{4}\right)$ or inorganic salts such as sodium silicate $\left(\mathrm{Na}_{2} \mathrm{SiO}_{3}\right)$ in the presence of a mineral acid (e.g., $\mathrm{HCl}$ ) or a base (e.g., $\mathrm{NH}_{3}$ ) as a catalyst (Rahman \& Padavettan, 2012, pp.1-15). The synthesis of spherical hollow silica particles from the sodium silicate solution with boric acid or urea as an additive was carried out by the ultrasonic spray pyrolysis method. This work dealt with the effect of four parameters (concentration of boric acid and urea, feed rate of a reactant, reaction temperature, and time) on the particle size and the standard deviation. As a result, the mean particle size and the standard deviation decreased with increasing of all parameters except urea (Kim et al, 2005, pp.193198). Ratanathavorn et al (2018, pp.1-5) studied the silica nanoparticles synthesis by the ultrasonic spray pyrolysis (USP) technique using tetraethylorthosilicate (TEOS) as a precursor in order to produce a fixative material for cream perfume fomulation. The results showed that the synthesis temperature of $500{ }^{\circ} \mathrm{C}$ provided the smallest size of silica nanoparticles, about $106 \mathrm{~nm}$. The particle size decreased from $347 \mathrm{~nm}$ to $106 \mathrm{~nm}$ when the synthesis temperature increased from $300{ }^{\circ} \mathrm{C}$ to 500 ${ }^{\circ} \mathrm{C}$.

Ultra-small hollow silica nanoparticles were synthesized using the prepared amorphous calcium carbonate (ACC) particles as a template. The ACC particles were firstly prepared by the carbonation method, where the procedure was conducted in the methanol solvent to form $\mathrm{Ca}\left(\mathrm{OCH}_{3}\right)_{2}$ layers on ACC particles. The methanol concentration effect on the morphology of ACC particles was also investigated (Nakashima et al, 2018, pp.904-908). ACC particles were prepared by the carbonation method via bubbling $\mathrm{CO}_{2}$ gas into calcium ions dispersing in the methanol solution. The effect of the methanol concentration on the $\mathrm{CaCO}_{3}$ formation was investigated. The $\mathrm{pH}$ of the ACC preparation was studied in a range of 9.4 and 10. After that, ultra-small HSNPs were synthesized using the prepared ACC particles in the one-pot process. The results suggested that the synthesis of HSNPs using ultra-small ACC particles via the one-pot process is one of the most effective methods to produce ultra-small HSNPs regarding energy and cost savings.

\section{Carbonation of silicate minerals in water solution}

For such a mineral carbonation process, all common silicate minerals like forsterite $\left(\mathrm{Mg}_{2} \mathrm{SiO}_{4}\right)$, antigorite $\left(\mathrm{Mg}_{3} \mathrm{Si}_{2} \mathrm{O}_{5}(\mathrm{OH})_{4}\right)$ and 
wollastonite $\left(\mathrm{CaSiO}_{3}\right)$ and their overall reaction rates are suitable for carbonation. The related reactions are given in Equations (2-4):

$$
\begin{aligned}
& \mathrm{Mg}_{2} \mathrm{SiO}_{4}(\mathrm{~s})+2 \mathrm{CO}_{2}(\mathrm{~g})+2 \mathrm{H}_{2} \mathrm{O}(\mathrm{l})= \\
& =2 \mathrm{MgCO}_{3}(\mathrm{~s})+\mathrm{H}_{4} \mathrm{SiO}_{4}(\mathrm{aq})+89 \mathrm{~kJ} / \mathrm{mol} \\
& \mathrm{Mg}_{3} \mathrm{Si}_{2} \mathrm{O}_{5}(\mathrm{OH})_{4}(\mathrm{~s})+3 \mathrm{CO}_{2}(\mathrm{~g})+2 \mathrm{H}_{2} \mathrm{O}(\mathrm{I})= \\
& =3 \mathrm{MgCO}_{3}(\mathrm{~s})+2 \mathrm{H}_{4} \mathrm{SiO}_{4}(\mathrm{aq})+64 \mathrm{~kJ} / \mathrm{mol} \\
& \mathrm{CaSiO}_{3}(\mathrm{~s})+\mathrm{CO}_{2}(\mathrm{~g})+2 \mathrm{H}_{2} \mathrm{O}(\mathrm{I})= \\
& =\mathrm{CaCO}_{3}(\mathrm{~s})+\mathrm{H}_{4} \mathrm{SiO}_{4}(\mathrm{aq})+90 \mathrm{~kJ} / \mathrm{mol}
\end{aligned}
$$

Stopic et al (2018, p.993) have shown the reaction path of direct forsterite carbonation for a synthesis of magnesium carbonate in aqueous solution without any deeper consideration of the formed silica particles as shown in Equations (5-7), but in the presence of additives: sodium bicarbonate, oxalic acid, and ascorbic acid (as shown in Equations (7-8). Although olivine is a mixed crystalline material ( $\mathrm{Mg}$, $\mathrm{Fe})_{2} \mathrm{SiO}_{4}$, for simplicity, olivine consists only of $\mathrm{Mg}_{2} \mathrm{SiO}_{4}$, namely forsterite. First, gaseous carbon dioxide dissolves in aqueous solution. Simultaneously, forsterite is dissolved in aqueous solution (Equation (5)) forming aqueous silicic acid, then it precipitates as amorphous silica (Equation (6)) which is a by-product, and lastly, magnesium ions and carbonate form magnesite as shown in Equation (7):

$$
\begin{aligned}
& \mathrm{Mg}_{2} \mathrm{SiO}_{4}(\mathrm{~s})+4 \mathrm{H}^{+}(\mathrm{aq}) \stackrel{r \mathrm{Mg}_{2} \mathrm{SiO}_{4}}{\longrightarrow} 2 \mathrm{Mg}^{2+}(\mathrm{aq})+\mathrm{H}_{4} \mathrm{SiO}_{4}(\mathrm{aq}) \\
& \mathrm{H}_{4} \mathrm{SiO}_{4}(\mathrm{aq}) \stackrel{r \mathrm{SiO}_{2}}{\longrightarrow} \mathrm{SiO}_{2}(\mathrm{~s})+2 \mathrm{H}_{2} \mathrm{O}(\mathrm{l}) \\
& \mathrm{Mg}^{2+}(\mathrm{aq})+\mathrm{CO}_{3}^{2-}(\mathrm{aq}) \stackrel{r \mathrm{MgCO}_{3}}{\longrightarrow} \mathrm{MgCO}_{3}(\mathrm{~s})
\end{aligned}
$$

This positive effect of additives may be due to "reaction-driven cracking" in the presence of $\mathrm{NaHCO}_{3}$, formation of etch pits, and/or other processes that continually renew the reactive surface area of $\mathrm{Mg}_{2} \mathrm{SiO}_{4}$.

$$
\mathrm{NaHCO}_{3}(\mathrm{aq}) \rightarrow \mathrm{Na}^{+}+\mathrm{H}^{+}+\mathrm{CO}_{3}{ }^{2-}
$$

The addition of oxalic acid leads to the formation of Mg-ions in the solution, which react with carbonate ions forming magnesium carbonate. 


$$
\mathrm{Mg}_{2} \mathrm{SiO}_{4}+2 \mathrm{H}_{2} \mathrm{C}_{2} \mathrm{O}_{4} \rightarrow 2 \mathrm{Mg}^{2+}+\mathrm{C}_{2} \mathrm{O}_{4}{ }^{2-}+\mathrm{H}_{4} \mathrm{SiO}_{4}
$$

The determination of the process parameters such as temperature, pressure and $\mathrm{pH}$ for maximum overall conversion rates is elementary. Direct $\mathrm{CO}_{2}$ sequestration at high pressure with olivine as a feedstock has already been performed in numerous studies at different temperatures and pressures with or without the use of additives such as carboxylic acid and sodium hydroxide. It is reported that optimal reaction conditions are in the temperature range of $150-185{ }^{\circ} \mathrm{C}$ and in the pressure range of 135-150 bar (Rahmani et al, 2014, pp.5953-5958). Additives are reported to have a positive influence on the carbonation rate, but without a study in detail. Optimal addition of additives is reported by (Béarat et al, 2006, pp.4802-4808) in studies about the mechanism that limits aqueous olivine carbonation reactivity under the optimum sequestration reaction conditions observed as follows: $1 \mathrm{M} \mathrm{NaCl}+0.64 \mathrm{M} \mathrm{NaHCO}_{3}$, at $185{ }^{\circ} \mathrm{C}$ and $\mathrm{P}\left(\mathrm{CO}_{2}\right)$ about 135 bar. A reaction limiting silica-rich passivating layer forms on the feedstock grains, slowing down carbonate formation and raising process costs.

Eikeland et al (2015, pp.5258-5264) reported that $\mathrm{NaCl}$ does not have significant influence on the carbonation rate, but, in the absence of $\mathrm{NaCl}$, the conversion rate amounted to more than $90 \%$ using a $\mathrm{NaHCO}_{3}$ concentration of $0.5 \mathrm{M}$. Ideally, the solid phases exist as pure phases without growing together. In reality, different observations are made on the behavior of solid phases. Daval et al (2011, pp.193-209) reported about a high influence of amorphous silica layer formation on the dissolution rate of olivine at $90{ }^{\circ} \mathrm{C}$ and at elevated pressure of carbon dioxide. This passivating layer, as shown in Fig. 5, may be either built up from non-stoichiometric dissolution, precipitation of amorphous silica on forsterite particles or from a combination of both.

These results suggest that the formation of amorphous silica layers plays an important role in controlling the rate of olivine dissolution by passivating the surface of olivine, an effect that has yet to be quantified and incorporated into standard reactive-transport codes. Queneau et al (1983) reported that the solubility of silica is sensitive to the $\mathrm{pH}$ level in alkaline solution, but relatively insensitive to $\mathrm{pH}$ in acid solution. Certain inorganic metallic impurities, particularly aluminium, can sharply reduce the rate of dissolution of silica. Unfortunately, these silica collectors are not effective in the $\mathrm{pH}$ range bellow 3 of concern to leaching of laterites with sulfuric acid. Therefore, a carbonation process of olivine in water solution at $175^{\circ} \mathrm{C}$ offers a possibility to avoid gel formation. 


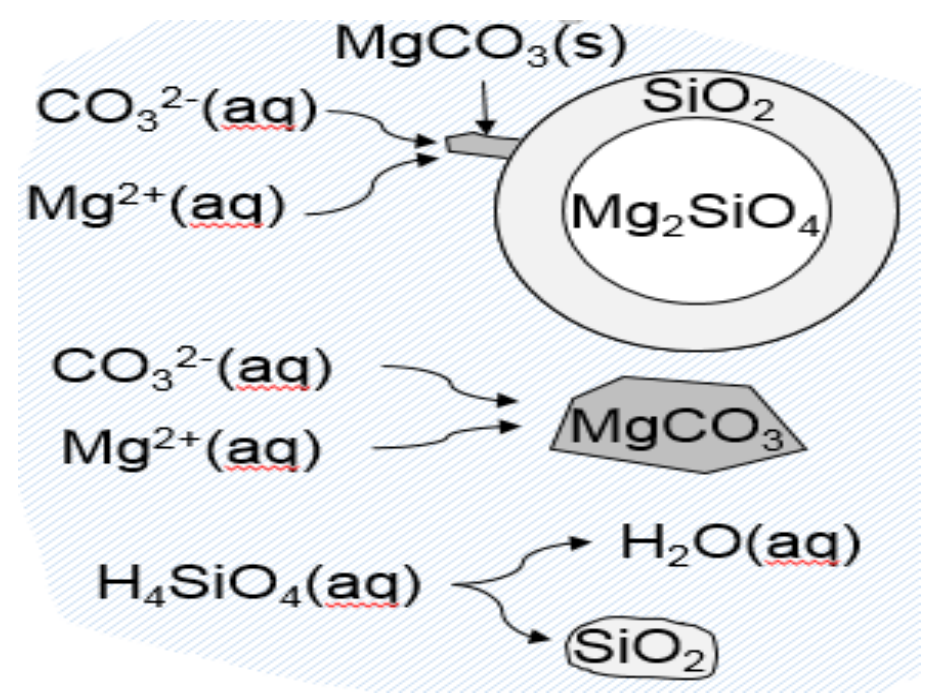

Figure 5 - The formation of the silica passivating layer

Puc. 5 - Образование слоя диоксида кремния, блокирующего карбонат магния

Слика 5 - Формирање слоја силицијумдиоксидом, који блокира магнезијумкарбонат

Stopic et al (2019, p.708) used Steinsvik olivine from Norway with a chemical analysis in (wt \%): $48.7 \mathrm{SiO}_{2}, 41.7 \mathrm{MgO}, 7.8 \mathrm{Fe}_{2} \mathrm{O}_{3}, 1.2 \mathrm{NiO}, 0$. $5 \mathrm{Al}_{2} \mathrm{O}_{3}, 0.4 \mathrm{Cr}_{2} \mathrm{O}_{3}, 0.2 \mathrm{CaO}, 0.1 \mathrm{ZnO}$ ) for the absorption of gaseous carbon dioxide. The treatment of olivine was performed using the operations such as milling, sieving, carbonation in an autoclave, filtration, and a chemical analysis of solid and liquid samples shown in Figure 6.

The carbonation tests were carried out in the $1500 \mathrm{~mL}$ autoclave from Büchi Kiloclave Type $3 \mathrm{E}$, at $175^{\circ} \mathrm{C}$ with 117 bar pure grade $\mathrm{CO} 2$ in the presence and the absence of additives such as sodium bicarbonate, oxalic acid, and ascorbic acid in duration of 2-4 h. Sample amount ranging from 100 to $300 \mathrm{~g}$ was added to the $1000 \mathrm{~mL}$ solution with a mixing rate of 600 revolutions per minute in different experiments. After the reaction, the liquid had very low content of metal cations and was analyzed via the ICP OES analysis. The characterization of the solid products was restricted to the XRD analysis and XRF analyses. 

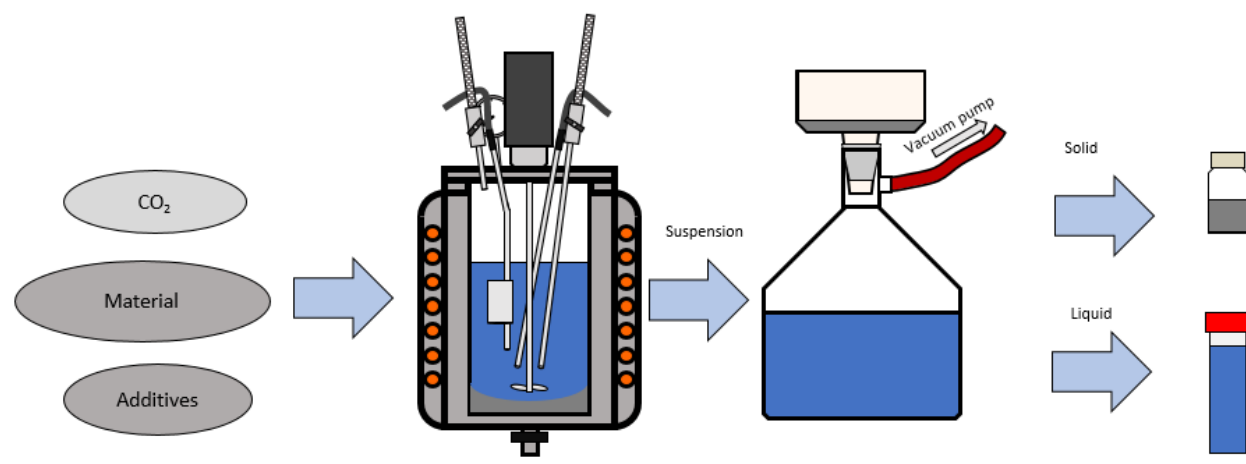

Figure 6 - Carbonation process of olivine and sampling

Puc. 6 - Процесс карбонизации оливина и отбор проб

Слика 6 - Процес апсорпције уәљен-диоксида и узимање проба

The presence of magnesite and silica was confirmed using the SEM analysis of the solid product, as shown in Figure 7.



Figure 7 - SEM analysis of the initial olivine sample after carbonation.

Puc. 7 - СЭМ Сканирующая электронная микроскопия исходного образца оливина после карбонизации

Слика 7 - Сканирајућа електронска микроскопска слика оливина након апсорпције угљен-диоксида

As illustrated by Figure 7, the SEM-analysis confirmed that very small particles of $\mathrm{SiO}_{2}$ and magnesite are formed as rhombohedrons or hexagonal prisms at the surface of partially carbonated magnesium silicate. The challenge of future work is the separation of the formed 
silica particles from the product and the determination of the ratio of the formed silica.

\section{Conclusion}

The acidic leaching of lateritic ores, high silicon bauxite, and eudialyte leads to the formation of silica gel which hinders the leaching process in order to recover nonferrous metals and rare earth elements. Adding sodium fluoride and using dry digestion offer a possibility to prevent gel formation. The second possibility is the carbonation of olivine in water solution under high pressure in an autoclave in the presence of additives such as hydrogen becarbonate, oxalic acid, and ascorbic acid at $175^{\circ} \mathrm{C}$. The formed silica particles are between 200 and $500 \mathrm{~nm}$ and have a spherical form. The influence of the parameters such as temperatture and pressure, $\mathrm{pH}-\mathrm{V}$ alue and concentration of additives has high importance in cotrolling the synthesis of nanosilica particles. Furthermore, the best parameter combinations will be studied in future work in order to offer an experimental design for the synthesis of silica particles.

\section{References}

Alkan, G., Yagmurlu, B., Gronen, L., Dittrich, C., Ma, Y., Stopic, S., \& Friedrich, B. 2019. Selective silica gel free scandium extraction from Irondepleted red mud slags by dry digestion. Hydrometallurgy, 185, pp.266-272. Available at: https://doi.org/10.1016/j.hydromet.2019.03.008.

Béarat, H., McKelvy, M.J., Chizmeshya, A.V.G., Gormley, D., Nunez, R., Carpenter, R.W.,...Wolf, G.H. 2006. Carbon Sequestration via Aqueous Olivine Mineral Carbonation: Role of Passivating Layer Formation. Environmental Science and Technology, 40(15), pp.4802-4808. Available at: https://doi.org/10.1021/es0523340.

Daval, D., Sissmann, O., Menguy, N., Saldi, G.D., Guyot, F., Martinez, I.,...Hellmann, R. 2011. Influence of amorphous silica layer formation on the dissolution rate of olivine at $90^{\circ} \mathrm{C}$ and elevated pCO2. Chemical Geology, 284(12), pp.193-209. Available at: https://doi.org/10.1016/j.chemgeo.2011.02.021.

Eikeland, E., Blichfeld, A.B., Tyrsted, C., Jensen, A., \& Iversen, B.B. 2015. Optimized Carbonation of Magnesium Silicate Mineral for CO 2 Storage. ACS Applied Materials and Interfaces, 7(9), pp.5258-5264. Available at: https://doi.org/10.1021/am508432w.

Hansen, T., \& Zander, N. 2011. Extraction of silica and magnesium compounds from olivine, European Patent !P 1373139 B1. 
Kim, K.D., Choi, K.Y., \& Yang, J.W. 2005. Formation of spherical hollow silica particles from sodium silicate solution by ultrasonic spray pyrolysis method. Colloids and Surfaces A: Physicochemical and Engineering Aspects, 254(1-3), pp.193-198. Available at: https://doi.org/10.1016/j.colsurfa.2004.12.009.

Ma, Y., Stopic, S., \& Friedrich, B. 2019. Hydrometallurgical Treatment of an Eudialyte Concentrate for Preparation of Rare Earth Carbonate. Johnson Matthey Technology Review, 63(1), pp.2-13. Available at: https://doi.org/10.1595/205651318x15270000571362.

Ma, Y., Stopic, S., Gronen, L., Milivojevic, M., Obradovic, S., \& Friedrich, B. 2018. Neural Network Modeling for the Extraction of Rare Earth Elements from Eudialyte Concentrate by Dry Digestion and Leaching. Metals, 8(4), p.267. Available at: https://doi.org/10.3390/met8040267.

Nakashima, Y., Takai, C., Razavi-Khosroshahi, H., Suthabanditpong, W., \& Fuji, M. 2018. Synthesis of ultra-small hollow silica nanoparticles using the prepared amorphous calcium carbonate in one-pot process. Advanced Powder Technology, 29(4), pp.904-908.

Available

at: https://doi.org/10.1016/j.apt.2018.01.006.

Olerud, S. 1998. Method for Manufacturing spherical silica from olivine, US Patent 5780005.

Queneau, P.B., Berggren, M.W, Cooperrider, M., \& Doane, R.E. 1983. Control of silica deposition during pressure let-down of acidic leach slurries, Hydrometallurgy, Research, Development and Plant Practice. In: 112th AIME Annual Meeting, March 6.

Rahman, I.A., \& Padavettan, V. 2012. Synthesis of Silica Nanoparticles by Sol-Gel: Size-Dependent Properties, Surface Modification, and Applications in Silica-Polymer Nanocomposites - A Review. Journal of Nanomaterials, 2012, pp.1-15. Available at: https://doi.org/10.1155/2012/132424.

Rahmani, O., Junin, R., Tyrer, M., \& Mohsin, R. 2014. Mineral Carbonation of Red Gypsum for CO 2 Sequestration. Energy and Fuels, 28(9), pp.59535958. Available at: https://doi.org/10.1021/ef501265z.

Ratanathavorn, W., Bouhod, N., \& Modsuwan, M. 2018. Synthesis of silica nanoparticles by ultrasonic spray pyrolysis technique for cream perfume formulation development. J. Food Health Bioenviron. Sci., 11(3), pp.1-5 [online]. Available at: https://www.tci-thaijo.org/index.php/sdust/article/view/183837. [Accessed: 21 December 2019]

Stopic, S., Dertmann, C., Koiwa, I., Kremer, D., Wotruba, H., Etzold, S.,...Friedrich, B. 2019. Synthesis of Nanosilica via Olivine Mineral Carbonation under High Pressure in an Autoclave. Metals, 9(6), p.708. Available at: https://doi.org/10.3390/met9060708.

Stopic, S., Dertmann, C., Modolo, G., Kegler, P., Neumeier, S., Kremer, D., ...Friedrich, B. 2018. Synthesis of Magnesium Carbonate via Carbonation under High Pressure in an Autoclave. Metals, 8(12), p.993. Available at: https://doi.org/10.3390/met8120993. 
Stopic, S., Friedrich, B., Schroeder, M., \& Weirich, T.E. 2013. Synthesis of $\mathrm{TiO}_{2} \quad$ core/ $/ \mathrm{RuO}_{2}$ shell particles using multistep ultrasonic spray pyrolysis. Materials Research Bulletin, 48(9), pp.3633-3635. Available at: https://doi.org/10.1016/j.materresbull.2013.05.050.

Zulfiqar, U., Subhani, T., \& Husain, S.W. 2016. Synthesis and characterization of silica nanoparticles from clay. Journal of Asian Ceramic Societies, 4(1), pp.91-96. Available at: https://doi.org/10.1016/j.jascer.2015.12.001.

\section{ОТЛОЖЕНИЕ КРЕМНИЯ В ГИДРОМЕТАЛЛУРГИЧЕСКИХ} ПРОЦЕССАХ

Сречко Р. Стопич, корреспондент, Бернд Г. Фридрих

Технический университет города Ахен,

Институт металлургических процессов и рециклирования металлов,

Ахен, Федеративная Республика Германия

РУБРИКА ГРНТИ: 61.13.21 Химические процессы

ВИД СТАТЬИ: обзорная статья

ЯЗЫК СТАТЬИ: английский

Резюме:

Введение/цель: Растворение цветных металлов из оксидных руд, таких как латерит, боксит с высоким содержанием кремния и эвдиалит, во время кислотной обработки было связано с образованием силикагеля.

Методы: Ознакомление с поведением кремнезема в гидрометаллургических процессах, таких как растворение при атмосферном и высоком давлении, осаждение, нейтрализация и фрильтрация, оказалось весьма важным при извлечении металлов из водного раствора.

Результаты: Предотвращение гелеобразования стало возможным благодаря использованию раствора $c$ высокой концентрацией кислот («сухой раствор») и абсорбции диоксида углерода из оливина при высоком давлении в автоклаве.

Выводы: Изготовление мелкодисперсного порошка кремнезема из оливина в водном растворе было достигнуто при $175^{\circ} \mathrm{C} \mathrm{u}$ 120 бар и в течение 4 часов в автоклаве с использованием добавок, таких как бикарбонат натрия и щавелевая кислота. Ключевые слова: кремний, гидрометаллургия, гель, диоксид кремния.

ТАЛОЖЕЊЕ СИЛИЦИЈУМ-ДИОКСИДА У ХИДРОМЕТАЛУРШКИМ ПРОЦЕСИМА

Срећко Р. Стопић, аутор за преписку, Бернд Г. Фридрих

Технички универзитет у Ахену, Институт за процесну металургију и рециклирање метала, Савезна Република Немачка 


\section{ОБЛАСТ: хемијске технологије} ВРСТА ЧЛАНКА: прегледни рад ЈЕЗИК ЧЛАНКА: енглескИ

\section{Сажетак:}

Увод/сврха: Растварање обојених метала из оксидних руда, као uто су латерити, боксити са високим садржајем силицијума и еудиалит, коришћењем киселина повезано је са стварањем гела од силицијум-диоксида.

Meтоде: Сличност са понашањем силицијум-диоксида у хидрометалуриким процесима, као ито су растварање при атмосфрерском и високом притиску, таложење, неутрализација и филтрирање, од великог је значаја за извлачење метала из раствора.

Резултати: Избегавање формирања гела омогућено је коришћењем растварања великим концентрацијама киселина („суво растварање”) и апсорпцијом угљен-диоксида од оливина при високом притиску у аутоклаву.

Закључак: Припрема фриног праха силицијум-диоксида из оливина у воденом раствору постигнуто је на $175^{\circ} \mathrm{C}$ и 120 бара за 4 cama y аутоклаву коришћењем додатака као ито су натријумбикарбонат и оксална киселина.

Кључне речи: силицијум, хидрометалургија, гел, силицијумдиоксид.

Paper received on / Дата получения работы / Датум пријема чланка: 13.11.2019. Manuscript corrections submitted on / Дата получения исправленной версии работы / Датум достављања исправки рукописа: 28.12.2019.

Paper accepted for publishing on / Дата окончательного согласования работы / Датум коначног прихватања чланка за објављивање: 30.12.2019.

(C) 2020 The Authors. Published by Vojnotehnički glasnik / Military Technical Courier

(www.vtg.mod.gov.rs, втг.мо.упр.срб). This article is an open access article distributed under the terms and conditions of the Creative Commons Attribution license (http://creativecommons.org/licenses/by/3.0/rs/).

(c) 2020 Авторы. Опубликовано в «Военно-технический вестник / Vojnotehnički glasnik / Military Technical Courier» (www.vtg.mod.gov.rs, втг.мо.упр.срб). Данная статья в открытом доступе и распространяется в соответствии с лицензией «Creative Commons» (http://creativecommons.org/licenses/by/3.0/rs/).

(C) 2020 Аутори. Објавио Војнотехнички гласник / Vojnotehnički glasnik / Military Technical Courier (www.vtg.mod.gov.rs, втг.мо.упр.срб). Ово је чланак отвореног приступа и дистрибуира се у складу са Creative Commons licencom (http://creativecommons.org/licenses/by/3.0/rs/).

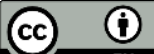

